\title{
The development of the public benefit requirement for charitable trusts in the nineteenth century
}

\author{
MATTHEW MILLS
}

The first express judicial reliance on the public benefit requirement for charitable trusts to conclusively determine charitable validity seems to occur in 1862, although implied references to similar ideas are seen up to a century previously. With limited exceptions, the origin of the public benefit requirement has been under-examined. This article argues that a multi-factorial and contextual approach best explains its adoption in the nineteenth century. Three developments in nineteenth century law and society encouraged judges to broaden charity law: (1) increasing religious pluralism, (2) increasing state education, and (3) regular income taxation. These changes, combined with the formalisation of the doctrine of precedent, required both some limit on the scope of charity law and a new substantive justification for novel decisions on charitable validity. This article argues that judges and lawyers, whether intentionally or subconsciously, borrowed ideas of public benefit from closely-related mortmain cases to develop the public benefit requirement.

Keywords: charity, charitable trust, public benefit, nineteenth century, mortmain.

\section{INTRODUCTION}

It is now well settled that to create a valid charitable trust, the settlor must intentionally settle property on trust for a charitable purpose which is for the 'public benefit'. ${ }^{1}$ This latter requirement is known as 'the public benefit requirement' and at common law it encapsulates two ideas: first, that the nature of the purportedly-charitable purpose must be a benefit to the community; and second, that those who benefit from the purportedly-charitable purpose must be sufficiently numerous to constitute a 'section of the public'. ${ }^{2}$ The Charities Act 2011

\footnotetext{
${ }^{1}$ Charities Act 2011 ss 2(1), 4(1).

${ }^{2}$ Independent Schools Commission ('ISC') v Charity Commission [2011] UKUT 421 (TCC); [2012] Ch 214, [44], and $A G v$ Charity Commission [2012] UKUT 420, [2012] WTLR 977, [30]. See text to n 11.
} 
preserves the existence of the public benefit requirement and its existing common law understanding. ${ }^{3}$

Unsurprisingly, most academic commentary in this area has focussed on delineating the current case law concerning the public benefit requirement, ${ }^{4}$ and there have been few comprehensive attempts at exploring its precise origins and historical path ${ }^{5}$ (despite notable explanations for the history of charitable trusts more generally ${ }^{6}$ ). The aim of this article is a specific exploration of the history of the public benefit requirement for charitable trusts. It will be shown that, despite a relatively long history of usage, with judges explicitly using the public benefit requirement to determine charitable validity since 1862, and perhaps implicit references extending one hundred years beforehand, ${ }^{7}$ a single reason for the emergence of the public benefit requirement remains elusive. Instead, the best explanation, similar to the history of nineteenth century contract law, is multi-factorial and contextual. ${ }^{8}$

This article argues that the need for the nineteenth century development of the public benefit requirement for charitable trusts was the result of four coinciding factors: (1) increased religious pluralism, (2) the birth of state education, (3) the birth of regular income taxation, and (4) the formalisation of the doctrine of legal precedent. Until now, only the increase in religious pluralism has been suggested as an influencing factor, ${ }^{9}$ however this article suggests that the first three of the above changes collectively broadened the types of charitable giving attempted in the nineteenth century. This meant that judges needed to find a way of justifying their attempts to broaden or contain charity law to cope with social change, whilst adhering to the recently-emerging doctrine of precedent. To do this, it will be argued that nineteenth century judges borrowed ideas of benefit to the public found in earlier mortmain case law, a very different context, to create the public benefit requirement.

\footnotetext{
${ }^{3}$ Charities Act 2011 s.4(3).

${ }^{4}$ Mary Synge, The 'New' Public Benefit Requirement: Making Sense of Charity Law?, Hart, 2015; Matthew Harding, Charity Law and the Liberal State, Cambridge, 2014; Jonathan Garton Public Benefit in Charity Law, Oxford, 2013; Jeffrey Hackney, 'Charities and Public Benefit', 124 Law Quarterly Review (2008), 347; and Matthew Harding, 'Trusts for Religious Purposes and the Question of Public Benefit', 71 Modern Law Review (2008), 159.

${ }^{5}$ Garton, Public Benefit, 18-23; and Pauline Ridge's work on religious charitable trusts: Pauline Ridge, 'Legal Neutrality and Religious Charitable Purposes', 31 Journal of Legal History (2010), 177; and Pauline Ridge, 'Religious Charitable Status and Public Benefit in Australia', 35 Melbourne University Law Review (2011), 1071 .

${ }^{6}$ David Owen, English Philanthropy 1660-1960, Cambridge, MA, 1969; Gareth Jones, The History of the Law of Charity: 1532-1837, Cambridge, 1969; and Michael Chesterman, Charities, Trusts and Social Welfare, London, 1979.

${ }^{7}$ Rickard v Robson (1862) 31 Beav 244.

${ }^{8}$ David Ibbetson, A Historical Introduction to the Law of Obligations, Oxford, 2001, chs 11-13; and James Gordley, The Philosophical Origins of Modern Contract Law, Oxford, 1993, chs 6-7.

${ }^{9}$ In the work of Pauline Ridge - see $\mathrm{n} 5$.
} 
To support this argument, four steps will be taken. First, three incorrect hypotheses will be identified and the relevance of the modern bifurcation of public benefit will be explained. Second, to give chronology to the inquiry, the history of the usage of legal remarks concerning the need for public benefit for a valid charitable trust, both implied and explicit, will be mapped. Third, the four contextual factors which created the background to the adoption of the public benefit requirement will be explored. Finally, this article will show how nineteenth century judges borrowed ideas of public benefit from earlier mortmain case law to formally adopt the public benefit requirement for charitable validity.

\section{A USEFUL FRAMEWORK AND THREE INCORRECT HYPOTHESES}

Before we begin, three incorrect hypotheses must be discarded as irrelevant to our historical analysis: the relevance of a presumption of public benefit, the relevance of cy-près, and the supposed purpose of charity under the Statute of Charitable Uses $1601 .{ }^{10}$ However, it will be explained that the modern trend of separating out different senses within the public benefit requirement is a helpful tool to analyse the nineteenth century case law.

\section{Distinct components of public benefit: a useful framework}

At least since 1953, commentators have sought to distinguish two components of the public benefit requirement - first, the charitable trust confers a benefit on society, and second, the benefit accrues to a sufficiently wide class of people. ${ }^{11}$ Recently, a similar distinction was accepted by the Upper Tier Tribunal in the Independent Schools Council case where it distinguished 'public benefit in the first sense', which requires the nature of the purpose to be a benefit to the community, from 'public benefit in the second sense', which requires those who benefit from the charity to be sufficiently numerous to constitute a 'section of the public'. ${ }^{12}$

Two recent commentators have distinguished further principles within the public benefit requirement. Professor Jonathan Garton has persuasively distinguished four components in the public benefit requirement. ${ }^{13}$ For Garton, the public benefit requirement: identifies the abstract purposes which are charitable ('conceptual public benefit'); determines whether meaningful benefit results from carrying out a particular purpose ('demonstrable

\footnotetext{
1043 Eliz. I, c.4.

${ }^{11}$ G. H. L. Fridman, 'Charities and Public Benefit', 31 Canadian Bar Review (1953), 537.

12 Independent Schools Commission v Charity Commission [2012] Ch 214, [44]; repeated AG v Charity Commission [2012] WTLR 977, [30].

${ }^{13}$ Garton, Public Benefit, chs 2-6; for Garton's summary see 45-49.
} 
public benefit'); determines the extent to which access to the benefits of a particular charitable purpose can legitimately be restricted ('cross-sectional public benefit'); and determines whether private benefit is incidental or fundamental ('incidental private benefit'). Garton's classification is thoroughly researched and explains classic difficulties found within the twofold classification of the public benefit requirement. For example, a gift to a school for pickpockets is not charitable because there is no demonstrable public benefit - even though there is conceptual public benefit in the form of public education. ${ }^{14}$

Somewhat amalgamating the two, Dr Mary Synge has suggested 'an alternative framework on which guidance on the public benefit requirement might have been based'. ${ }^{15}$ Synge's framework is comprised of two tests, which roughly match the Upper Tribunal's two senses of public benefit, and seven disqualifying sub-principles covering the rules against political, illegal, detrimental or mainly-non-charitable purposes, as well as the rules regulating private gain, personal nexus and numerical sufficiency amongst beneficiaries. However, Synge explicitly admits her purpose is not to delineate the principles of public benefit in detail, and refers her reader to 'fuller explanations' in the works of Garton and others. ${ }^{16}$ Therefore, this article will focus more on Garton's classification as well as the Upper Tribunal's.

At first blush, these modern sources cite no explicit nineteenth century sources which distinguish distinct components of the public benefit requirement. For example, Fridman relies almost exclusively on cases post-1930, ${ }^{17}$ Picarda's leading textbook only cites cases post$1900,{ }^{18}$ and even Garton almost exclusively discusses cases post-1940. This is to be expected from works aimed at elaborating the current case law.

However, as will be seen below, the early cases did not speak entirely in one voice when discussing public benefit. Different judges seemed to use the public benefit requirement in either its first or second sense, although only two cases even impliedly discuss both senses with respect to the same issue. ${ }^{19}$ Therefore, although it seems that the distinctions outlined above were not always explicitly in the minds of nineteenth century judges, the public benefit requirement was from its earliest days not just one requirement. Accordingly, both the 'orthodox' dual classification of public benefit in the first and second sense used by the Upper

\footnotetext{
${ }^{14}$ Re Macduff [1896] 2 Ch 451, 474 (Rigby LJ).

${ }^{15}$ Synge, The 'New' Public Benefit Requirement, 25-26.

${ }^{16}$ Ibid, 25, fn 51, also referring readers to Hubert Picarda, The Law and Practice Relating to Charities, 4th ed., London, 2010, and Peter Luxton, The Law of Charities, Oxford, 2001.

${ }^{17}$ Fridman, 'Public Benefit'.

${ }^{18}$ E.g. Picarda, Law and Practice, ch 2.

${ }^{19}$ Hall v Derby Urban Sanitary Authority (1885) 16 QBD 163 and Re Nottage (No. 1) [1895] 2 Ch 649.
} 
Tribunal, ${ }^{20}$ and Garton's fourfold terminology, will be used to explain precisely what the public benefit requirement demanded in the early cases.

\section{A presumption of public benefit: an incorrect hypothesis}

Professor Matthew Harding ${ }^{21}$ and the Charity Commission ${ }^{22}$ have suggested that implicit presumptions of public benefit operated for centuries. However, none of the old cases relied on in either argument show any actual reliance on presumptions, let alone explicit usage of such a phrase. Instead, what we see is judges taking notice of incontrovertibly-beneficial purposes ${ }^{23}$ or personally investigating the purpose to conclude 'the benefits speak for themselves' ${ }^{24}$ Crucially, the cases relied upon concern very common and clearly beneficial charitable purposes but for religions which were not legally tolerated at that point. This meant that judges were skipping over charitable validity without discussion of public benefit to apply the doctrine of cy-près and/or to avoid intestacy. ${ }^{25}$ Therefore, the orthodox position, that 'presumptions' of public benefit cannot be traced further back than the 1940s, ${ }^{26}$ seems justified, and the idea of a presumption of public benefit need not feature in our historical analysis.

\section{The relevance of cy-près: an incorrect hypothesis}

One might attempt to rely on the doctrine of cy-près to explain the development of the public benefit requirement. Cy-près refers to the power of the court to apply charitable trust property for other, similar charitable purposes where the intended purpose cannot be carried out precisely as intended by the donor. The development of a (broad) public benefit requirement as the key criterion in charitable validity could be explained as a means by which the courts gave a broad definition to charity to facilitate the use of cy-près to assist charitable giving and

\footnotetext{
${ }^{20}$ Harding, Charity Law, 13.

${ }^{21}$ Harding, 'Religious Purposes', 161-166, arguing that a 'natural association of religion and charity performed a role similar to that played by the presumption of public benefit in modern cases' (at 162-3).

${ }^{22}$ Decision of the Charity Commission on the Registration of the Preston Down Trust, 3 January 2014, paragraphs 37-43:

<https://www.gov.uk/government/uploads/system/uploads/attachment_data/file/336112/preston_down_trust_ful 1_decision.pdf > accessed 15 August 2016.

${ }^{23}$ Synge, The 'New' Public Benefit Requirement, 22-24; for example: in AG v Baxter (1684) 1 Vern 248 and $A G$ $v$ Hickman (1732) 2 Eq Cas Abr 193 that a charity to support impecunious and/or unemployed ministers would prima facie be valid; or in Cary v Abbot (1802) 7 Ves Jun 490 that a charity to fund the Catholic education and raising of poor orphans is valid.

${ }^{24}$ Garton, Public Benefit, 106; for example, in Thornton v Howe (1862) 31 Beav 14, 18 (Sir John Romilly MR).

${ }^{25}$ As occurred in all three cases cited at $\mathrm{n} 23$ above. In Thornton $v$ Howe the charitable trust was upheld.

${ }^{26}$ Independent Schools Commission v Charity Commission [2012] Ch 214, [62], citing National Anti-Vivisection Society [1948] 31, 41-42 (Lord Wright).
} 
deter unscrupulous claimants. ${ }^{27}$ Alternatively, a narrow definition of charity, not based on the broad public benefit requirement, would have given the court greater control over the availability of the benefits of charity law. Whilst these suggestions are theoretically sensible, they are not accurate as none of the key cases ever mention cy-près, despite its longstanding existence by the nineteenth century. ${ }^{28}$

\section{The 'purpose of charity law': an incorrect hypothesis}

Ridge has argued that, given that the purpose of the Statute of Charitable Uses 1601 was to encourage benevolence to help relieve widespread Elizabethan poverty, '[i]t was uncontroversial... that purposes coming within the spirit and intendment of the preamble must provide some public benefit'. ${ }^{29}$ In support, Ridge cites a chapter from Jones' work on the history of charity. ${ }^{30}$ This argument would seemingly explain the origins of the public benefit requirement.

However, three responses may be made. First, poverty was only one example of the types of charity the 1601 Act discussed; for example, the Act also discusses the 'Repaire of Bridges Portes Havens Causwaies Churches Seabankes and Highwaies'. In the section of his work Ridge cited in support of her argument, Jones himself recognises the relief of poverty was only the Act's 'principal manifestation', not a prerequisite. ${ }^{31}$ Second, the actual purpose of the Act was not concerned with redefining the law of charity - rather its purpose was to remedy the widespread misappropriation of funds given to charitable uses. ${ }^{32}$ Third, even if the statute was aimed at promoting the public benefit this does not necessarily mean that 'aiming at the public benefit' was made a definitional element of a charitable trust. Turning an underlying idea into a definitional element is a very modern approach to law, and one that does not fit with nineteenth century charity cases. In short, Ridge's argument does not accurately reflect how the Act was understood at the time or during the nineteenth century, so it need not be considered further. ${ }^{33}$

\footnotetext{
${ }^{27}$ Compare mortmain discussion; section VI.

${ }^{28}$ Sheridan and Delaney suggest the first known use of the idea of cy-près in English law was in Sir T. Littleton, Treatise on Tenures (c. 1481) in the context of conditions precedent; Lionel Sheridan and Vincent Delaney, The Cy-près Doctrine, London, 1959, 5-10. Although the precise origins of its use in English charity law are obscure, it was a developed doctrine by the early seventeenth century: Jones, History, 74.

${ }^{29}$ Ridge, 'Legal Neutrality', 201.

${ }^{30}$ Jones, History, ch 8, 120-127.

${ }^{31}$ Ibid, 127; Re Macduff [1896] 2 Ch 451, 464 (Lindley LJ).

32 J. C. Brady, 'The law of charity and judicial responsiveness to changing social need', 27 Northern Ireland Law Quarterly (1976), 198, 199.

${ }^{33}$ George Spence, The Equitable Jurisdiction of the Court of Chancery, vol. 1, 1846, 586-587.
} 


\section{THE PUBLIC BENEFIT REQUIREMENT - A BROADER HISTORY}

Before 1736, judges had rarely been asked to consider whether a particular trust was charitable or not; the main question with which they had to deal, if any, was whether a particular trust amounted to a superstitious use. ${ }^{34}$ However, as the issue of charitable validity became more commonly raised in court, judges chiefly asked whether charitable purposes were within the wording or the 'spirit and intendment' of the Statute of Charitable Uses 1601 to determine charitable validity. ${ }^{35}$ No substantive guidance seems to have been given on what 'within the spirit and intendment' means, so as time went by it was inevitable that some more concrete guidance would be needed on what constitutes a valid charitable trust.

As section IV will show, the first express judicial use of the public benefit requirement to conclusively determine charitable validity seems to occur in $1862 .{ }^{36}$ This section will track the other sources which implicitly, obiter or non-judicially discussed before 1862 the need for public benefit for valid charitable trusts. Although numerous charity-related Acts of Parliament were enacted throughout the nineteenth century, ${ }^{37}$ none of them mentions anything like a public benefit requirement. ${ }^{38}$ Therefore, this section will focus on other sources, and will consider implied judicial references, arguments of counsel, other primary sources and contemporaneous academic material.

\section{Implied judicial references}

From the mid-eighteenth century, we see judges making implied references to the need for public benefit in charitable trusts. ${ }^{39}$ At first, these references were largely either obiter, confined to a particular context, or broad rhetorical phrases meant more as a description or explanation of the result, rather than a prescriptive requirement on which charitable validity depended. This was often because the desired outcome could be achieved by the application of

\footnotetext{
${ }^{34}$ Jones, History, 58 and 120.

35 The phrase comes from Morice v Bishop of Durham (1804) 9 Ves Jr 399, 405 (Sir William Grant MR), and (1805) 10 Ves Jr 522, 541 (Lord Eldon LC). However, the idea can arguably be traced back further to AGv Ruper (1722) 2 P Wms 125, 126 (Sir Joseph Jekyll MR) and Turner v Ogden (1787) 1 Cox 316, 317 (Sir Lloyd Kenyon MR). Jones traces the idea back to Moore's Reading on the Statute of Charitable Uses in 1607: Jones, History, 26, 58 and 120-121.

${ }^{36}$ Rickard v Robson (1862) 31 Beav 244.

${ }^{37}$ E.g. Charities Procedure Act 1812 (53 Geo. III, c.101); Charities, etc. (England) Act 1817 (57 Geo. III, c.39); Charitable Commissioners Act 1831 (1 \& 2 Will. IV, c.34); Charitable Trusts Act 1853 (16 \& 17 Vict., c.137); Charitable Uses Act 1861 (24 \& 25 Vict., c.9); Mortmain and Charitable Uses Act 1888 (51 \& 52 Vict., c.42).

${ }^{38}$ Although the phrase 'charitable or public purposes' appeared in section 16 of the Succession Duty Act 1853 , 16 \& 17 Vict. c.51, it was not interpreted to constitute a public benefit requirement.

${ }^{39}$ Jones, History, 58 and 120.
} 
a different legal principle. However, given the frequency and strength of such rhetoric, it is easy to see how, over time, references to the need for public benefit might have evolved, or could have been turned, from a descriptive obiter reason for a particular decision to a prescriptive requirement which novel purposes had to satisfy to determine charitable validity.

In $A G v$ Pearce in 1740, Lord Hardwicke stated that 'in the extensiveness of the benefit accruing from [the purportedly charitable dispositions] they may very properly be called publick charities'. ${ }^{40}$ This phrase, which seems like a broad statement of the second sense of the public benefit requirement (cross-sectional benefit), was cited in at least one later judgment. ${ }^{41}$

Importantly, however, Pearce concerned a gift for the relief of the poor of a parish. 'Poor relations' charitable trusts originally counted as private charity, but only public charities could be enforced by the court (hence the adjective 'public' being a key issue in poverty cases). ${ }^{42}$ We must therefore be wary of conflating judicial discussion of 'public benefit' and discussions of the public-private charity distinction. Thus, given that Pearce is also our earliest reference, we should treat it with some scepticism as the source of the public benefit requirement. However, Pearce and Nash v Morley, which repeats Lord Hardwicke's quotation, are the only relief of poverty charitable trust cases considered in this article so any potential widespread conflation of public-private poverty trusts rhetoric and the public benefit requirement is unlikely. Furthermore, Lord Hardwicke used similar language in a non-poverty charitable trust case only ten years later, decreasing the risk of such conflation.

In $A G v$ Whorwood (1750), Lord Hardwicke held that a gift for a fellow of University College, Oxford to live in the testator's house was not charitable because it was established only to allow one person to live in his house - this meant it 'answer[ed] no good to the college or the public'. ${ }^{43}$ This was similar language to that used by the unnamed counsel, who argued that the gift was valid because colleges 'are bodies of universal extent and benefit to mankind'. ${ }^{44}$ In Whorwood, Lord Hardwicke appears to use the second sense of public benefit (incidental private benefit) to invalidate a prima facie valid educational trust. Importantly, however, this issue was strictly obiter as Lord Hardwicke was merely deciding whether the

\footnotetext{
402 Atk 87, 88 .

${ }^{41}$ Nash v Morley (1842) 5 Beav 177, 184 (Lord Langdale MR).

${ }^{42}$ E.g. Anon (1745) 3 Atk 277, 277 (Lord Hardwicke LC), Ommanney v Butcher (1823) Turn \& R 260, 273-274 (Sir Thomas Plumer MR); Nash v Morley (1842) 5 Beav 177, 183 (Lord Langdale MR); William Boyle, A Practical Treatise on the Law of Charities, London, 1837, 294-301.

${ }^{43} 1$ Ves Sen 534, 537.

${ }^{44}$ Ibid, 534.
} 
Attorney General was the correct person to bring the claim; he explicitly said 'I will give no opinion at present' on the validity of the charitable trust. ${ }^{45}$

Despite these caveats, Pearce and Whorwood were widely publicised before the end of the eighteenth century, repeating the obiter remarks that benefit to a sufficient section of the public was relevant to charitable trust validity. ${ }^{46}$ This connection began to reappear over the next century.

For example, in 1767, Lord Camden curtly stated: 'Definition of charity; a gift to a general public use, which extends to the poor as well as to the rich' ${ }^{47}$ Although probably not intended to be the definitive legal definition of a charitable trust, for a long time Lord Camden's quotation seemed the closest the law came to it. Hence this phrase was cited by at least two practitioner works ${ }^{48}$ and in argument by counsel in three cases (including one of our express judicial usage cases, Cocks $v$ Manners). ${ }^{49}$ Despite the requirement that a charitable purpose extends to the poor being abandoned within sixty years, ${ }^{50}$ if it ever was taken seriously, Lord Camden's quotation was later repeated by three judges across the nineteenth century; repeated verbatim by Lord Lyndhurst ${ }^{51}$ and Wigram $\mathrm{VC},{ }^{52}$ and repeated without the final clause by Lord Hailsham LC. ${ }^{53}$ Lord Camden's statement seems to be the first case to raise public benefit in the first (conceptual) sense. This potentially explains its appeal to judges and commentators wishing to extrapolate principles to apply in later cases. However, like our first two quotations, Lord Camden's remarks should also be caveated as they were made in the peculiar context of a mortmain dispute (the significance of which will be explained in section VI below).

Our fourth implied judicial reference to the public benefit requirement comes in 1792. In Grieves $v$ Case, the Court of Chancery held that land devised to poor dissenting ministers of certain chapels 'was a charitable use, in respect of the benefit the congregations were meant to derive from the preaching of their teachers'. ${ }^{54}$ Unfortunately, no further reasons are recorded

\footnotetext{
45 Ibid, 537.

46 Anthony Highmore, Addenda to the Law of Charitable Uses, London, 1793, 3; and Several Gentlemen, An abridgment of the modern determinations in the courts of law and equity: being a supplement to Viner's Abridgment, vol. 1, London, 1799, 92.

47 Jones $v$ Williams (1767) Amb 651, 652.

${ }^{48}$ Highmore, Addenda, 3, and Anthony Burrill, A New Law Dictionary and Glossary, vol. 1, New York, 1850, 205.

${ }^{49}$ Doe v Copestake (1805) 6 East 328, 332 (Vaughan Sjnt); Walker v Richardson (1837) 2 M \& W 882, 888 (Alexander, Addison and Grey); Cocks v Manners (1871) LR 12 Eq 574, 581 (Mr Morgan QC and Mr Karslake QC).

${ }^{50} A G v$ Heelis (1824) 2 Sim \& St 67, 76 (Leach VC).

${ }^{51}$ Mitford v Reynolds (1842) 1 Phillips 185, 191.

${ }^{52}$ Nightingale v Gouldburn (1847) 5 Hare 484, 487.

${ }^{53}$ Special Commissioners for Income Taxation v Pemsel [1891] AC 531, 543-544.

${ }^{54}$ Grieves v Case (1792) 4 Bro C C 67, 70.
} 
on this issue, but it seems that the court's focus was on what the public is meant to derive. This is arguably a reference to the first sense of public benefit (demonstrable public benefit) as the court seems concerned with what, conceptually, the particular charitable purpose would provide the public. However, the phrase 'in respect of' suggests the court stopped short of saying that in all cases a trust is charitable because it is for the public benefit, so at best this is an implied reference. Furthermore, Grieves was another mortmain case so its remarks must be seen in that peculiar context (explained in section VI below).

Finally, in 1824 Leach VC stated that funds given 'for any legal, public or general purpose, are charitable funds to be administered by Courts of Equity'. ${ }^{55}$ This is certainly well short of an explicit public benefit requirement in the first sense (conceptual public benefit), although that is because Leach VC believed it was the source of a fund which determined its charitable status rather than its purpose so there would simply have been no need to require public benefit. ${ }^{56}$ Despite this, within fifty years this quotation was cited by judges in three subsequent cases, implying such connections were actually in judges' minds and not mere rhetorical flourishes. ${ }^{57}$

Thus, from the mid-eighteenth century we see statements about the public nature of charitable trusts which roughly map the first and second senses of the public benefit requirement. Often these early statements are only rhetorical descriptions of the instant charity or obiter remarks. However, the repeated nature of these statements mean that over the nineteenth century we begin to see suggestions that the public nature of a charity can and should be used to help determine charitable validity. This is the natural precursor to judicial adoption of a new prescriptive requirement.

\section{Counsel's references}

Simultaneously, we see a similar trend in reported arguments of counsel, demonstrating a kind of intellectual feedback loop with judges' remarks. These arguments occur at a time when the specialist Chancery bar increased in size fivefold, with common law barristers 'seldom' arguing cases in Chancery. ${ }^{58}$ This was also at a time when the merging of the equity and common law courts raised the possibility of common law judges hearing technical equity cases.

\footnotetext{
${ }^{55}$ AG v Heelis (1824) 2 Sim \& St 67, 76.

${ }^{56}$ Ibid, 77. This idea was later discredited in AGv Eastlake (1853) 11 Hare 205, 222 (Page-Wood VC) and Hall $v$ Derby Urban Sanitary Authority (1885) 16 QBD 163, 171 (Manisty J).

${ }^{57}$ AG v Shrewsbury Corporation (1843) 6 Beav 220, 230 (Lord Langdale MR); AG v Eastlake (1853) 11 Hare 205, 221 (Page-Wood VC); Beaumont v Oliveira (1868) LR 6 Eq 534, 538 (Stuart VC, first instance).

${ }^{58}$ William Cornish, J. Stuart Anderson, Ray Cocks, Michael Lobban, Patrick Polden and Keith Smith, The Oxford History of the Laws of England Volume XI: English Legal System (1820-1914), Oxford, 2010, 1050.
} 
In such an arrangement, non-expert judges were possibly more easily influenced by intuitive public benefit arguments from specialist Chancery advocates, potentially encouraging the slip from description to prescription for public benefit in charity law.

In the seminal Morice v Bishop of Durham ${ }^{59}$ we see references by four different barristers to public benefit in the first sense (demonstrable public benefit) - interestingly, from both sides of the dispute. The testator purported to make a trust for 'such objects of benevolence and liberality as the trustee in his own discretion shall most approve'. At first instance, Samuel Romilly and Mr Bell argued that the word 'liberality' could not be charitable, 'not even importing any thing of a public nature; from which the public is to derive any benefit' ${ }^{60}$ Similarly, on appeal Mr Richards and Mr Martin argued that 'upon the authorities almost every thing, from which the public derive benefit, may be considered a charity', ${ }^{61}$ although the report cites no authorities for this proposition. Both courts held the disposition void on the ground that 'liberality' was so much wider than 'charity' that it was impossible to define and enforce by the court, so public benefit did not feature heavily in either judgment. However, Morice is important because it marked a turning point in religious charitable trusts generally, and arguably led to the explicit discussion of a public benefit requirement in Cocks v Manners. ${ }^{62}$

Within three years, Samuel Romilly again references public benefit in the first sense. In $A G v$ Fowler, Romilly (along with Mr Cooke) argued that '[ $\mathrm{t}$ ]o the description of a Charity, in the enlarged sense of this Court, two qualities are attached: 1 st, it must be a public benefit' ${ }^{63}$ Unlike in Morice, here Romilly seems to positively state public benefit in the first sense (demonstrable public benefit) as a requirement of charitable validity. Although this may have been necessary for Romilly's overarching position - that a Protestant dissenting chapel could not be the subject of a charitable trust - it is repeated arguments like this, coupled with judicial inexperience, which could have caused the public benefit issue to slide from being a description to a requirement in judges' minds.

In 1815, John Bosanquet argued that '[a]ll the cases respecting charitable uses have been, where some public benefit has been intended, not for the testator's own benefit' ${ }^{64}$ This reference to the invariable presence of, but not need for, public benefit in the second sense

\footnotetext{
${ }^{59}$ (1804) 9 Ves Jr 399; upheld on appeal (1805) 10 Ves Jr 522.

${ }^{60}$ Ibid, (1804), 400.

${ }^{61}$ Ibid, (1805), 523.

${ }^{62}$ Ridge, 'Religious Charitable Status', 1076.

63 (1808) 15 Ves Jr 85, 86.

${ }^{64}$ Thompson $v$ Pitcher (1815) 6 Taunt 359, 366.
} 
(incidental private benefit) was used to successfully claim that a gift of land to support a family tomb was not charitable. ${ }^{65}$

In 1832, while arguing that the keeping of a stock of corn for the local market was a charity, Sir Edward Sugden and Mr Bethell submitted that '[a] provision for building or repairing bridges, or doing any other act for the public benefit, is a charity' ${ }^{66}$ This suggests that (conceptual) public benefit in the first sense is invariably present in valid charities. Although again this stops just short of suggesting a requirement of public benefit in the first sense, it is another example of lawyers linking actions for the public benefit and charitable trusts.

Interestingly, the final example of counsel arguing for any kind of public benefit requirement comes just two years before judges started relying on the requirement, and after a lapse of nearly thirty years. In 1860, Mr Higgins argued that a testamentary gift for twenty 'aged spinsters and widows' of a particular parish 'is void as a gift to charity; it is neither a gift for any purpose of general public utility nor for the relief of poverty' ${ }^{67}$ This goes further than the previous quoted arguments of counsel as it suggests that a lack of public benefit in the first sense (conceptual public benefit) renders a charitable trust void.

\section{Other primary sources}

Two other primary sources have some relevance: a reading by Sir Francis Moore and the publications of the Charity Commissioners.

It has been claimed ${ }^{68}$ that in a reading on the Statute of Charitable Uses in 1607, Sir Francis Moore "emphasised... that all charitable uses were "publique" uses'. ${ }^{69}$ This is interesting because Moore was potentially one of the drafters of the statute; this would arguably tie the public nature of charitable trusts to the origins of charitable trusts law. ${ }^{70}$ Regardless, although Moore's own manuscript apparently contained this reference, ${ }^{71}$ this author can find no such quotation in any of the three original published versions of Moore's reading. ${ }^{72}$

\footnotetext{
${ }^{65}$ See mortmain discussion; section VI.

${ }^{66}$ AG $v$ The Haberdashers' Company (1832) 5 Sim 478, 481.

${ }^{67}$ Thompson v Corby (1860) 27 Beav 649, 649.

${ }^{68}$ Jones, History, 121 (unreferenced); Garton, Public Benefit, 18.

${ }^{69}$ Supposedly reproduced in George Duke, The Law of Charitable Uses, London, 1676, 129.

${ }^{70}$ Ibid, title page; $A G v$ Brown (1818) 1 Swanston 265, 307 (Lord Eldon LC); AG v Haberdashers' Company (1834) 1 M \& K 420, 428 (Lord Broughman LC); Boyle, Practical Treatise, 1837, 465; and Brady, 'Charity and Judicial Responsiveness', 200. This is disputed by Jones, History, 233-4.

${ }^{71}$ Cambridge University Library Manuscript, MS. Hh. III. 2.

${ }^{72}$ George Duke, The Law of Charitable Uses, London, 1676 and reprinted, London, 1805; and Boyle, Practical Treatise, 1837, 465-505. Even the modern abridged reprintings do not include the reference: Jones, History,
} 
Furthermore, even if the quotation were correct, it is nearly 150 years before we see even broad judicial suggestions of the public benefit requirement for a valid charitable trust. ${ }^{73}$ Therefore, unless Moore's copy of the reading was later (re)printed in an unknown source, the quotation above cannot have been too influential.

An alternative source is provided by the publications of the Charity Commission, which was permanently established in $1853 .{ }^{74}$ The vast majority of their work was concerned with trustee management and cy-près applications,${ }^{75}$ however they did sometimes discuss issues of charitable validity. ${ }^{76}$ For example, between 1872 and 1895 the Charity Commissioners considered the charitable validity of at least seven purported charitable gifts to maintain tombs. ${ }^{77}$ However, in none of these cases were issues of public benefit raised either by the Charity Commissioners or by the counsel advising them. This is unsurprising; the main focus of the Charity Commissioners was on converting unusual or unsuccessful charitable purposes to useful, 'normal' charitable purposes rather than pushing the boundaries of charitable validity, where issues of public benefit are most likely to be relevant. Furthermore, even when decisions of the Charity Commissioners were appealed, the courts essentially treated the matter as one of (what we now call) procedural administrative review rather than a substantive legal appeal of the Commissioners' decision itself. ${ }^{78}$ This meant that in deciding appeals the courts focussed on whether the Commissioners had exceeded their powers or had made a 'gross miscarriage' in making their decision - not on whether the particular judge would have settled the money on a (substantively) slightly different trust. ${ }^{79}$ In short, the nature of the work the Charity Commissioners undertook was unlikely to give rise to discussions of public benefit in the context of charitable validity, so their publications are not an overly useful source for present purposes.

\section{Textbooks and dictionaries}

240-249 and G. Jones, 'Francis Moore's Reading on the Statute of Charitable Uses' (1967) Cambridge Law Journal 224, 233-238.

${ }^{73} A G v$ Pearce (1740) 2 Atk 87; AG $v$ Whorwood (1750) 1 Ves Sen 534.

${ }^{74}$ Charitable Trusts Act 1853 (16 \& 17 Vict., c.137). The Administration of Endowed Charities Act 1860 (23 \& 24 Vict., c.136).

75 James J Fishman, 'Charitable Accountability and Reform in Nineteenth-Century England: The Case of the Charity Commission', 80 Chicago-Kent Law Review (2005), 723.

${ }^{76}$ In Charity Commission: Board of Commissioners, Cases and Opinions of Counsel 1872 to $31^{\text {st }}$ March 1895 (The National Archives, Char 16/1), only two out of thirty-six recorded legal issues considered by the Charity Commissioners in the period solely concerned charitable validity.

${ }^{77}$ Ibid, 55 and 231.

${ }^{78}$ In re Campden (1881) 18 Ch D 310, 331 (Sir George Jessel MR).

${ }^{79}$ Ibid. 
In addition to primary sources, we see occasional references to public benefit in connection with charitable trusts in select contemporaneous legal textbooks and dictionaries. (Numerous treatises did not mention charitable trusts at all, ${ }^{80}$ or, if they did, did not mention anything like a public benefit requirement ${ }^{81}$ ).

Before 1900, there are relatively few textbooks which mention any kind of public benefit requirement. In 1793 Highmore describes Jones $v$ Williams and cites Lord Camden's 'definition' of a valid charity. ${ }^{82}$ It is then not until 1860 that we see Finlason explaining that gifts for the maintenance of priests 'would be, according to English law, charitable - the benefit being general, not special and personal' (emphasis in original). ${ }^{83}$ Describing the general rule, Finlason states that '[a] charitable trust... is one which is for the benefit of others than the donor or his family, and is not merely for personal but general objects' (emphasis in original). ${ }^{84}$ However, this discussion was largely concerned with trusts for Roman Catholics in light of the Roman Catholic Charities Act 1831 and was not necessarily intended to be of general application. ${ }^{85}$

The final two references to public benefit in textbooks appear in quick succession. In his 1888 textbook, Tyssen states that the key question for the court when assessing charitable validity is to ask: 'is it not for the public benefit that property should be devoted for ever to fulfilling the purpose named? If the court considered that it was not for the public benefit, it held the trust altogether void'. ${ }^{86}$ He later devotes six pages to discussing the related issue of the distinction between public and private charity ${ }^{87}$ Unfortunately, it is not clear which sense(s) of the public benefit Tyssen was talking about; the quotation above is not clear and Tyssen's discussion simply cites the conclusions of cases which have affirmed particular purposes as public charitable trusts.

\footnotetext{
${ }^{80}$ E.g. George Goldsmith, The Doctrine and Practice of Equity, 2nd ed., Philadelphia, 1843; Arthur Underhill, Concise Manual on the Law Relating to Private Trusts and Trustees, 1st ed., London, 1878; Henry Godefroi, Digest of the Principles of the Law of Trusts and Trustees, London, 1879; Frederick White and Owen Tudor, A Selection of Leading Cases in Equity, 1st -6th eds., Philadelphia, 1849-1886.

${ }^{81}$ E.g. John Herne, The Law of Charitable Uses, London, 1663; Anon, A General Abridgment of Cases in Equity, 5th ed., London, 1793; Henry Ballow, A Treatise of Equity, 5th ed., London, 1820; Leonard Shelford, $A$ Practical Treatise of the Law of Mortmain and Charitable Uses and Trusts, London, 1836; Boyle, Practical Treatise, 1837; Thomas Lewin, A Practical Treatise on the Law of Trusts and Trustees, 1st and 2nd eds., London, 1837 and 1845; James Hill, Practical Treatise on the Law Relating to Trustees, London, 1845; Spence, Equitable Jurisdiction, 1846.

${ }^{82}$ Highmore, Addenda, 3.

${ }^{83}$ William Finlason, A brief and practical exposition of the Law of Charitable Trusts, London, 1860, 31.

${ }^{84}$ Ibid, 36-37.

852 \& 3 Will. VI, c. 115.

${ }^{86}$ Amherst Tyssen, Charitable Bequests, 1st ed., London, 1888, 5.

${ }^{87}$ Ibid, 187-193.
} 
Tyssen seems to view public benefit as more explicitly relevant to charitable trusts than Tudor. Tudor's leading textbook does not mention anything like a public benefit requirement in its first two editions. ${ }^{88}$ This is despite all five of our implied judicial references to public benefit having occurred over thirty years previously. However, in Tudor's third edition in 1889 he states that '[g]ifts for public and general purposes... are held to be charitable within the intent of the Statute of Elizabeth' ${ }^{89}$ Although an indirect reference to public benefit, this reaffirms that the nineteenth century was a key period of development for the public benefit requirement.

Legal dictionaries were another popular resource for eighteenth and nineteenth century lawyers. As expected, some dictionaries did not define anything relevant to charitable trusts, ${ }^{90}$ and those that did often provided unhelpfully circular definitions. ${ }^{91}$ However, Burrill's dictionary cites Lord Camden's 'definition' of charity from Jones $v$ Williams alongside a suggested definition of 'charitable' as 'for a useful and public purpose' ${ }^{92}$ This is potentially a reference to (conceptual) public benefit in the first sense. Furthermore, although in his Abridgement Viner discusses cases where the validity of the words used in the purportedly charitable disposition was considered, the closest he comes to suggesting a public benefit requirement is in describing cases which evidence obvious public benefit. ${ }^{93}$

This inconsistency in the relevance of public benefit leaves a gap between our useful sources from 1793 until 1860. Interestingly, this is exactly the same period in which the usage of public benefit begin the transition from obiter rhetoric to prescriptive requirement.

\section{Conclusion to the broader history}

The broader history of the public benefit requirement suggests that 1740 until 1860 was a key period of development. During this 120 year period the public nature of charitable trusts begins to evolve from offhand remarks about particular charities, to a common factor in charitable trusts law cited by judges, barristers and textbook writers. Indeed, at the very end of this period we see counsel arguing that a lack of public benefit in the first sense renders a charity void;

\footnotetext{
${ }^{88}$ Owen Tudor, The Law of Charitable Trusts, 1st and 2nd eds., London, 1854 and 1862.

${ }^{89}$ Ibid, 3rd ed., London, 1889, 11.

${ }^{90}$ E.g. John Rastell, Les Termes de la Ley, London, 1629 - 1812 eds.; John Cowell, The Interpreter of Words and Terms, final ed., London, 1701.

${ }^{91}$ E.g. in Giles Jacob, The New Law Dictionary, 4th ed., London, 1739, 'charitable uses' are defined as 'land etc given to charitable uses'. In later editions (13th ed., 1811 and the 1835 ed.) they are defined as 'giving for the maintenance of a school, a hospital or any other charitable use'.

92 Alexander Burrill, Law Dictionary, 1st - 3rd ed., New York, 1850-1871, 205.

${ }^{93}$ Viner's Abridgement, vol. 1, London, 1799, 88-91, discussing AG v Whorwood (1750) 1 Ves Sen 534-and Grieves v Case (1792) 4 Bro C C 67.
} 
although this argument was not commented on by the judge in the case, such arguments are the necessary precursor to judicial acceptance of the public benefit requirement. It is against this background that the history of the public benefit requirement as a determinative principle in court judgments will now be mapped.

\section{THE PUBLIC BENEFIT REQUIREMENT - ITS HISTORY IN JUDGMENTS}

Although the public benefit requirement was only written into English statute in $2006,{ }^{94}$ and the distinction between its first and second senses only formally judicially recognised in $2011,{ }^{95}$ we see judges explicitly relying on the public benefit requirement alone to conclusively determine issues of charitable validity over 140 years earlier. As explained above, before then judges had chiefly asked whether charitable purposes were within the spirit and intendment of the Statute of Charitable Uses 1601 to determine charitable validity.

The first case in which public benefit was held expressly to be decisive of charitable validity seems to be in Rickard $v$ Robson in 1862. There, using similar language to counsel, Sir John Romilly $\mathrm{MR}^{96}$ says 'a gift merely for the purpose of keeping up a tomb or building which is of no public benefit, and only an individual advantage, is not a charitable use but a perpetuity'. Conversely, 'if the gift is to keep up an institution for the benefit of the public, then it is clearly a charity'. ${ }^{97}$ Romilly MR thus holds that public benefit in the second sense is a necessary condition for a charitable trust as a trust yielding 'only an individual advantage' is not a charity; this arguably raises both cross-sectional public benefit and incidental private benefit. Romilly MR, however, did not attempt to distinguish between the two senses of public benefit; indeed, his judgment seems to conflate the two by suggesting that the trust was not charitable under the Statute of Charitable Uses 1601 (the first sense; conceptual) because it did not provide benefit to a sufficient section of the population (the second sense; cross-sectional).

Less than seven years later, in Beaumont v Oliveira the Court of Appeal in Chancery held that testamentary gifts to the Royal Geographic Society and the Royal Society 'subsist for [educational] purposes and no others, therefore for public purposes-therefore, for the advancement of objects of general public utility—-therefore for purposes analogous and similar

\footnotetext{
${ }^{94}$ Charities Act 2006 s 3.

${ }^{95}$ Independent Schools Commission v Charity Commission [2012] Ch 214.

${ }^{96}$ It seems to be a mere interesting coincidence that Sir John Romilly MR and his father, Sir Samuel Romilly, are both prominent in the development of the public benefit requirement.

${ }^{97}$ Rickard v Robson (1862) 31 Beav 244, 246 (Sir John Romilly MR), 245 (Mr Walford, counsel).
} 
to those mentioned in the statute of Elizabeth-therefore for charitable purposes' ${ }^{98}$ Although this scatter-gun reasoning aims to cover all possible justifications for a finding of charity to support the court's desired result, within it is a clear suggestion that if a charity's purpose provides public benefit in the first sense (conceptual public benefit) then it will be a valid charitable trust. Therefore, Beaumont uses public benefit in the first sense being to justify the validity of a new type of charitable trust. It is interesting to observe that both senses of the public benefit requirement can arguably be traced to cases in the 1860s, although those cases did not distinguish the two.

The third explicit judicial reference is from the important 1871 case of Cocks $v$ Manners. ${ }^{99}$ In discussing the validity of testamentary gifts to two orders of Roman Catholic nuns, Wickens VC stated that 'religious purposes are charitable, but that can only be true as to religious services tending directly or indirectly towards the instruction or the edification of the public'. ${ }^{100}$ Because one of the donees was a set of cloistered nuns, Wickens VC accordingly used the lack of public benefit in the first sense (demonstrable public benefit), as the purpose did not 'tend' to meaningful benefit, to justify invalidating the purported religious charitable trust. ${ }^{101}$ This seems to be the first example of public benefit in the first sense being used to invalidate a purported charitable trust. Unfortunately, however, Wickens VC seems to conflate Garton's two parts of public benefit in the first sense by suggesting that a religious trust for cloistered nuns was 'neither within the letter nor the spirit' of the Statute of Charitable Uses 1601 (conceptual) because such a trust would not tend to benefit to the public (demonstrable). ${ }^{102}$

In 1875 , the Privy Council adopted a similar approach. ${ }^{103}$ A testatrix had left a will directing, amongst other things, 'that a house for performing religious ceremonies to my late husband and myself be erected'. ${ }^{104}$ The court held that 'gifts for purposes useful and beneficial to the public... in a wide sense of the term, are called charitable uses' (conceptual public benefit). ${ }^{105}$ Applying this principle, 'the only point therefore requiring consideration can be, whether there is anything... which would render such [a disposition] beneficial or useful to the

\footnotetext{
${ }^{98}$ Beaumont v Oliveira (1868-69) LR 4 Ch App 309, 315 (Selwyn LJ, giving the judgment of the court).

${ }^{99}$ Ridge, 'Legal Neutrality', 178, where Ridge, possibly exaggeratedly, claims it is the 'first reported decision to require public benefit'. Garton simply treats this case as another example of courts finding a trust noncharitable where it only provided a private benefit: Garton, Public Benefit, 19.

${ }^{100}$ Cocks v Manners (1871) LR 12 Eq 574, 585.

${ }^{101}$ Ibid.

102 Ibid.

${ }^{103}$ Yeap Cheah Neo v Ong Cheng Neo (1874-75) LR 6 PC 381.

${ }^{104}$ Ibid, 382.

105 Ibid, 394.
} 
public'. ${ }^{106}$ The court concluded that the disposition 'does not seem to fall within any definition of a charitable duty or use. The observance of it can lead to no public advantage, and can benefit or solace only the family itself' ${ }^{107}$ Once more we see the court using a lack of public benefit in the second sense (incidental private benefit) to justify invalidating a purported religious charitable trust.

A thinly-reasoned example arose in the House of Lords in $1882 .{ }^{108}$ In upholding the charitable status of oyster fishing rights held by the Saltash Corporation for the benefit of Saltash freemen, Earl Cairns stated that it was 'a charitable, that is to say a public, trust or interest, for the benefit of the free inhabitants of ancient tenements' ${ }^{109}$ Although no substantive discussion was given to why such an arrangement involves a charitable trust, the conclusion that the charitable trust was valid seems to be premised on the presence of (conceptual) public benefit in the first sense. This quotation was cited three times in 1888, including by Lindley LJ who, just five years later, gave his own version of the public benefit requirement. ${ }^{110}$ Earl Cairns also alluded to (cross-sectional) public benefit in the second sense to justify his conclusion when he stated that the trust would not be void for being 'for the benefit of private individuals or a fluctuating body of private individuals'. ${ }^{111}$

In 1885 we find our first clear use of the public benefit requirement in the second sense in upholding a charitable trust. Derby Railway Servants Orphanage applied to court to confirm that it was exempt from district rates under the Public Health Act 1875 on the basis that it occupied its property 'exclusively for the purposes of public charity'. ${ }^{112}$ In holding that the orphanage was such a charity, and exempt from the rates, Manisty $\mathbf{J}$ assumed that its purposes were charitable in nature. ${ }^{113}$ The only question was thus "whether this charity is not for a large and extensive section of the community' to qualify as a public charity under the Act. ${ }^{114}$ After citing Lord Hardwicke's remarks from Pearce, extracted above, ${ }^{115}$ Manisty $\mathrm{J}$ concluded that

\footnotetext{
106 Ibid, 395.

107 Ibid, 396.

108 Goodman v Saltash Corporation (1882) 7 App Cas 633.

${ }^{109}$ Ibid, 650.

${ }^{110}$ Re Christchurch Inclosure (1888) 88 Ch D 520, 532 (Lindley LJ); Re St Stephen (1888) 39 Ch D 492, 500-501 (Kay J); Re Norwich Town Close Estate Charity (1889) LR 40 Ch D 298, 307 (Cotton LJ); Re White [1893] 2 Ch 41, 52 (Lindley LJ).

${ }^{111}$ Goodman v Saltash Corporation (1882) 7 App Cas 633, 650.

11238 \& 39 Vict. c.55, s.211(1)(c), preserving the exemption under Local Government Supplemental (No. 2) Act $1859,22 \& 23$ Vict. c. 11, which itself preserved the original exemption under s. 103 of An Act for better paving and otherwise improving the borough of Derby, 6 Geo. IV, c.132 (1766).

${ }^{113}$ Hall v Derby Urban Sanitary Authority (1885) 16 QBD 163, 170.

114 Ibid, 171.

${ }^{115} A G v$ Pearce (1740) 2 Atk 87, 88 .
} 
'this charity is extensive. It extends to the whole of the railway servants all over England'. ${ }^{116}$ This short decision contains what seems to be the first use of the second sense of the (crosssectional) public benefit requirement to justify upholding charitable status. Furthermore, Manisty J's decision impliedly suggests a difference between being charitable in nature (conceptual public benefit) and being for the benefit of a sufficient section of the public (crosssectional public benefit) - arguably implying a difference between two senses of public benefit.

In the late 1880s two further decisions at first instance held that a lack of public benefit in the second sense (incidental private benefit) justified invalidating a purported religious charitable trust. First, in 1886 North $\mathrm{J}$ cited and followed the above passages from Romilly MR's judgment in Rickard to hold that a charitable trust to keep in repair a churchyard was 'for the benefit of the parish at large', but a trust to keep in repair a family tomb was 'only ministering to [the testator's] own private feeling or pride'. ${ }^{117}$ Second, in 1888 Chitty J applied Cocks $v$ Manners to hold that a gift to a society who privately prayed for the suppression of animal cruelty was not charitable because 'a mere improvement of the individual by private prayer... is not a purpose of public or general utility within the statute'. ${ }^{118}$

In 1891, the House of Lords handed down the seminal decision in Pemsel, a case concerning the meaning of 'charitable purpose' within the Income Tax Act 1842. ${ }^{119}$ In holding that the technical English meaning should apply to that phrase, Lord Macnaghten famously stated: "Charity" in its legal sense comprises four principal divisions: trusts for the relief of poverty; trusts for the advancement of education; trusts for the advancement of religion; and trusts for other purposes beneficial to the community, not falling under any of the preceding heads' (emphasis added). ${ }^{120}$ Although this section merely intended to 'clear the ground' for the rest of the judgment, ${ }^{121}$ Lord Macnaghten's fourth category seems to turn public benefit in the first sense into a formal, abstract, 'catch-all' category of valid charitable trusts. Furthermore, the House of Lords appeared to use reasoning based on (conceptual) public benefit in the first sense to justify upholding the charitable status of a new type of charity.

In the 1893 decision of Re White, ${ }^{122}$ which concerned bequests to unstated 'religious societies', the Court of Appeal confirmed Cocks v Manners and that a lack of (demonstrable)

\footnotetext{
${ }^{116}$ Hall v Derby Urban Sanitary Authority (1885) 16 QBD 163, 172.

${ }^{117}$ Re Vaughan (1886) 33 Ch D 187, 192-193.

${ }^{118}$ Re Joy (1888) 60 LT 175, 180.

${ }^{119}$ Special Commissioners for Income Taxation v Pemsel [1891] AC 531; 5 \& 6 Vict., c.35.

120 Special Commissioners for Income Taxation v Pemsel [1891] AC 531, 583; this is very similar to the categorisation of charitable purposes Samuel Romilly suggested as counsel in Morice v Bishop of Durham (1805) 10 Ves Jr 522, 532.

${ }^{121}$ Special Commissioners for Income Taxation v Pemsel [1891] AC 531, 584.

122 [1893] 2 Ch 41.
} 
public benefit in the first sense can invalidate a purported religious charitable trust. Lindley $\mathrm{LJ},{ }^{123}$ giving the judgment of the court, stated that '[a] society for the promotion of private prayer and devotion by its own members, and which has no wider scope, no public element, no purposes of general utility, would be a "religious" society, but not a "charitable" one'. ${ }^{124}$ On the facts, however, since no particular religious societies were named the court assumed the trust would be charitable.

Finally, in 1895, two relevant charitable trust cases were decided within three months which relied on different senses of the public benefit requirement. In the first, Chitty J, using similar language to his 1888 judgment, stated that ' $[\mathrm{t}$ ]o be a charity there must be some public purpose - something tending to the benefit of the community'. ${ }^{125}$ Applying this, Chitty $\mathbf{J}$ accepted that gifts to support anti-vivisection organisations could be charitable trusts since they were for the public benefit in the first sense (conceptual public benefit). Interestingly, Chitty $\mathbf{J}$ also stated that 'whether, if [the organisations] achieved their object, the community would, in fact, be benefited is a question on which I think the Court is not required to express an opinion'. ${ }^{126}$ This suggests that at least Chitty $\mathrm{J}$ regarded positive proof of demonstrable public benefit as unnecessary for charitable validity; it is unclear whether he would have also stated a proven lack of such benefit is irrelevant. By 1895, we thus cannot be sure that the courts distinguished the different senses of the public benefit requirement.

In the second 1895 case, Re Nottage (No 1), both Kekewich J and the Court of Appeal held invalid a bequest to support the Yacht Racing Association and establish a yachting competition. ${ }^{127}$ Kekewich J stated that 'in order to find that a gift is charitable, the Court must come to the conclusion that the benefit of the community is the direct, and not the remote, object of the gift' but concluded that the purported charity did not do this. ${ }^{128}$ Kekewich J thus seems to be the first judge to rely on a refined version of the first sense of the public benefit requirement (demonstrable public benefit) to invalidate a purported charitable trust because the nature of the benefit to the community from the Yacht Racing Association was too indirect. On

\footnotetext{
${ }^{123}$ Although Lindley LJ and Wickens VC had been involved in the same charitable trust cases when advocates (e.g. AG v Bishop of Manchester (1866-67) LR 3 Eq 436), and when Wickens was elevated to the bench (e.g. Re Meyricke Fund (1871-72) LR 13 Eq 269), there is no evidence this influenced either of their opinions on the public benefit requirement.

${ }^{124}$ Re White [1893] $2 \mathrm{Ch} 41,52$. Lindley had run a broadly similar, but inverted, argument as an advocate in 1866, when he claimed that ' $[\mathrm{t}]$ he profits... are dedicated to a charity, and, therefore, it is for the public benefit': Letton v Goodden (1866) LR 2 Eq 123, 128.

${ }^{125}$ Re Foveaux [1895] 2 Ch 501, 504.

${ }^{126}$ Ibid, 507.

${ }^{127}$ Re Nottage (No. 1) [1895] 2 Ch 649, 653-654; upheld on appeal at 655-656.

${ }^{128}$ Ibid, 653-654.
} 
appeal, Lopes LJ confirmed that the purported charitable trust was invalid but stated that this was because its object was 'the encouragement of a mere sport or game primarily calculated to amuse individuals apart from the community at large'. ${ }^{129}$ Lopes LJ seems to be relying on the second sense of the public benefit requirement (incidental private benefit) to justify the same conclusion as Kekewich $\mathrm{J}$; that the bequest did not create a charitable trust. Re Nottage thus confirms that both senses of the public benefit requirement were used by judges to invalidate purported charitable trusts, and that judges still had difficulty agreeing on which senses were relevant in each case.

To summarise, between 1862 and 1895 we see the public benefit requirement explicitly used to determine charitable validity in twelve different judgments, five of which were at Court of Appeal level or higher. Importantly, in these first cases we see different senses of the public benefit requirement being distinguished. We see in the early cases judges using both of the two senses of the public benefit requirement as distinguished by the Upper Tribunal in the Independent Schools Council case (that the nature of the purpose benefits the community and that a sufficiently numerous cross-section are benefited). We also see those judges using all four of Garton's elements of public benefit (conceptual pubic benefit, demonstrable public benefit, cross-sectional public benefit and incidental private benefit). However, sadly these different senses or elements were never clearly distinguished. We also see the two senses of the public benefit from the Independent Schools Council case being used to justify both validating and invalidating a purported charitable trust; this is true for Garton's demonstrable and cross-sectional public benefit, but not for conceptual public benefit (which was only used to validate) or incidental private benefit (which, unsurprisingly, was only used to invalidate). In short, proof of one aspect of public benefit could be used to justify the validation of a novel charitable trust (supporting, for example, anti-vivisection, the Royal Society or a town's oyster fishing rights) and the lack of one aspect could be used to invalidate a prima facie valid charitable trust (for example, a yachting cup or the maintenance of one's own grave). The only thing missing was a case explicitly discussing more than one aspect of the public benefit requirement to settle their independent existence and precisely when they were required.

\section{CONTEXTUALISING THE DEVELOPMENT OF THE PUBLIC BENEFIT REQUIREMENT}

${ }^{129}$ Ibid, 656. Rigby LJ seems to agree at 656. 
Sections III and IV have shown that by the late nineteenth century, following over 100 years of references to public benefit rhetoric by judges, barristers and commentators, the public benefit requirement had become an established conceptual tool in cases concerning charitable validity. However, exactly why public benefit made the transition from rhetoric to requirement when it did is never made clear, and is not helped by the fact that references to public benefit were often very brief. But despite the primary sources failing to clearly explain this development, they do give a chronology to it. This section will therefore consider the other legal and social factors which explain the development of the public benefit requirement throughout the nineteenth century.

The major political, social and economic changes of the nineteenth century led to fundamental changes in philanthropy. ${ }^{130}$ Indeed, from the late eighteenth century philanthropy became 'a social imperative' in the upper and middle classes, and the number of new charities being set up per year increased nearly threefold. ${ }^{131}$ These changes put a greater number of charitable 'experiments in benevolence' before the courts. ${ }^{132}$ The litigation relating to these experiments provided the courts with the perfect opportunity for doctrinal development as they had to decide whether these new types of purported charitable gifts were and should be valid and had to develop the law accordingly.

Four specific factors will for the first time be posited as the key catalysts for the development of the public benefit requirement: (1) increased religious pluralism, (2) the birth of state education, (3) the birth of regular income taxation, and (4) the formalisation of the doctrine of precedent.

\section{Nineteenth century religious pluralism}

Thus far, the growth of religious pluralism in the nineteenth century is the only factor relevant to the development of the public benefit requirement which has received extended academic treatment. That treatment is largely constituted by the work of Professor Pauline Ridge, on whose work this sub-section draws. ${ }^{133}$ However, this article goes further than Ridge in arguing that the growth in religious pluralism is only one relevant factor in the development of the public benefit requirement.

\footnotetext{
${ }^{130}$ Fishman, 'Charitable Accountability', 724 and 766.

${ }^{131}$ Owen, English Philanthropy, 73, 164-165 and 169-170.

132 Courtney Kenny, The True Principles of Legislation with Regard to Property given for Charitable or other Public Uses, London, 1880, 24-25.

${ }^{133}$ Pauline Ridge, 'Legal Regulation of Religious Giving' 157 Law \& Justice (2006) 17; Ridge, 'Legal Neutrality'; Ridge, 'Religious Charitable Status'.
} 
Before the Reformation, only one religion was recognised by law and the 'overwhelming majority' of people accepted it. Thus it was 'natural' for the law to accept that religion without question. ${ }^{134}$ This meant that, even after the Statute of Uses 1601, gifts to that religion were likely to be accepted as being beneficial to the community, 'unless the settlor had misconstrued advancement of the Christian religion' or 'harm was evident'. ${ }^{135}$ In other words, the probable validity of a religious charitable trust was linked to the acceptance of the religion the trust intended to support. ${ }^{136}$ Because, for a long time anyone supporting a religion which denied the Trinity could be punished, ${ }^{137}$ most religious charities were for common, wellaccepted purposes. Consequently, even into the nineteenth century almost all religious purposes were assumed to be charitable without much attention paid to why this was so. ${ }^{138}$

However, as society's attitude to religion started to relax, so did the law's. Aside from the Toleration Act 1689, ${ }^{139}$ which permitted the existence of most non-conformist Protestant groups, the early pace of change was relatively slow. This changed from the end of the eighteenth century. In just over half a century, the Toleration Act provisions were extended to Roman Catholic groups, ${ }^{140}$ Jewish groups, ${ }^{141}$ and Unitarian worship. ${ }^{142}$ More specifically, charitable trusts for most Roman Catholic, ${ }^{143}$ Unitarian, ${ }^{144}$ and Jewish ${ }^{145}$ groups were permitted from the mid-nineteenth century. Given the legal and financial benefits obtained by charitable status, ${ }^{146}$ as the nineteenth century progressed, the courts were increasingly confronted with diversity in religious giving. ${ }^{147}$ For example, charitable trusts supporting the Moravian Church's missionary efforts in 'heathen nations' and gifts to closed female Catholic orders. ${ }^{148}$

\footnotetext{
${ }^{134}$ Gilmour v Coats [1949] AC 426, 457 (Lord Reid).

135 Steve Woodfield, 'Doing God's Work: Is Religion Always Charitable?' 8 Auckland University Law Review (1996-99) 25, 31.

136 Robert Rhodes Jr, 'Pluralist Establishment: Reflections on the English Experience' 12 Cardozo Law Review (1990-1991) 867, 871.

${ }^{137}$ Blasphemy Act 1697 (9 \& 10 Will. III, c.32).

${ }^{138}$ Ridge, 'Legal Neutrality', 178; citing AG v Herrick (1772) Amb 712; Baker v Sutton (1836) 1 Keen 224,233 (Lord Langdale MR).

1391 Will. \& Mar., c. 18.

${ }^{140}$ Roman Catholic Relief Act 1791 (31 Geo. III, c.32).

${ }^{141}$ Religious Disabilities Act 1846 (9 \& 10 Vict., c.59).

${ }^{142}$ Doctrine of the Trinity Act 1813 (53 Geo. III, c.160).

${ }^{143}$ Roman Catholic Charities Act 1831 (2 \& 3 Will. VI, c.115).

144 The Dissenter's Trust Act 1844 (7 \& 8 Vict., c.45).

145 Ibid; Religious Disabilities Act 1846 (9 \& 10 Vict., c.59).

${ }^{146}$ Charitable trusts have financial and legal advantages compared to non-charitable trusts, or simple donation schemes; Simon Gardner, An Introduction to the Law of Trusts, 3rd ed., Oxford, 2011, 100-103.

${ }^{147}$ Ridge, 'Legal Regulation', 18.

${ }^{148}$ In Re The Moravian Society (1858) 26 Beav 101; Special Commissioners for Income Taxation v Pemsel [1891] AC 531; and Cocks v Manners (1871) LR 12 Eq 574.
} 
Simultaneously, women were increasingly becoming involved in and litigating such trusts as these 'newer' religious groups often offered greater opportunities for leadership. ${ }^{149}$

At a similar time, the old law of 'superstitious uses' was being relaxed. ${ }^{150} \mathrm{~A}$ superstitious use was a use "which has for its object the propagation of the rites of a religion not tolerated by law'. ${ }^{151}$ Such dispositions would be held invalid, although if 'a general intention of piety' could be discovered the gift would often be applied cy-près. ${ }^{152}$ There was 'no Statute making superstitious uses void generally', ${ }^{153}$ although there had been three pieces of legislation relevant to superstitious uses. ${ }^{154}$ However, those statutes were, respectively, mainly focussed on mortmain, only applied retroactively to the previous five years, and temporary. ${ }^{155}$ Despite this lack of solid statutory basis, there were frequent findings of superstitious uses from the sixteenth to eighteenth centuries. ${ }^{156}$ It was not until the aforementioned statutes officially accepted nonstandard religions that courts began to decrease the frequency of finding a charitable gift to be superstitious ${ }^{157}$ (although there were still some superstitious use cases ${ }^{158}$ ).

Throughout this period of social change, the law, and in particular the courts, had to substantively justify which forms of religion should be awarded charitable status. ${ }^{159}$ This task was more difficult than historically it had been. They could no longer rely on an assumed public consensus as to the value of all lawful religion; indeed, prejudices towards Catholicism led to suggestions that not all religious purposes were beneficial. ${ }^{160}$ However, courts could not distinguish religions arbitrarily. ${ }^{161}$ Some yardstick was therefore needed to enable courts to justify decisions on which religious charitable purposes would be upheld.

The courts adopted two strategies. First, as explained above, they focussed more closely on the Statute of Charitable Uses and only validated those purposes which fitted within the 'spirit and intendment' of the preamble to the Statute of Charitable Uses 1601 and its

\footnotetext{
${ }^{149}$ Ridge, 'Legal Neutrality', 184.

${ }^{150}$ See generally: Boyle, Practical Treatise, 242-277; Tudor, Charitable Trusts, 3rd ed., 18-25; T BourchierChilcott, 'Superstitious Uses' 36 Law Quarterly Review (1920), 152.

${ }^{151}$ Boyle, Practical Treatise, 242.

152 Ibid; Cary v Abott (1802) 7 Ves Jr 490.

${ }^{153}$ Cary $v$ Abott, (1802) 7 Ves Jr 490, 495 (Sir William Grant MR).

${ }^{154}$ Mortmain Act 1531 (23 Hen. VIII, c.10); 1 Edw. VI, c.14; 1 Geo. I, c.55.

${ }^{155}$ Cary v Abott (1802) 7 Ves Jr 490, 495 (Sir William Grant MR).

156 Tudor, Charitable Trusts, 3rd ed., $19 \mathrm{n}$.

${ }^{157}$ Ibid, 20-22.

${ }^{158}$ West v Shuttleworth (1835) 2 My \& K 684; Heath v Chapman (1854) 2 Drew 417; possibly Yeap Cheah Neo (1874-75) LR 6 PC 381, but the discussion was intertwined with the discussion of public benefit.

${ }^{159}$ Ridge, 'Legal Neutrality', 179.

${ }^{160}$ Ibid, 201; Ridge, 'Religious Charitable Status', 1076.

${ }^{161}$ Thornton $v$ Howe (1862) 31 Beav 14, 20 (Sir John Romilly MR).
} 
subsequent case law. The second strategy was to rely on the presence of public benefit. Given that the Statute of Charitable Uses only mentions one 'oblique' religious purpose - the 'Repaire of... Churches' - the 'culmination' of Morice was that in the majority of the difficult religious charity cases public benefit was key. ${ }^{162}$ This meant that religious charity cases provided the perfect proving ground for this nascent requirement. Indeed, nearly one third of the cases cited above for explicit and implicit support for a public benefit requirement are religious charity cases, ${ }^{163}$ and one of them, Cocks $v$ Manners, is believed to be the first decision on gifts to female religious orders under the Roman Catholic Charities Act 1831. ${ }^{164}$ This shows the magnitude and immediacy of the impact that religious pluralism had on the development of the public benefit requirement - from the very first case on a particular religious issue, the public benefit requirement was needed and explicitly came to the fore.

\section{The birth of state education}

At the start of the nineteenth century, creating and maintaining educational establishments was 'largely left to private initiative', with benefactors often using charitable trusts as a vehicle for making such gifts. ${ }^{165}$ However, from 1833 the state became increasingly involved in education nationwide, initially giving grants to educational initiatives and setting up educational commissions and, from 1870, providing primary schools where there were not enough private or church schools to serve all local children. ${ }^{166}$

Possibly as a result of the increase in the role taken by the state in the provision of education, the mid-nineteenth century saw a correlative decrease in the importance and number of educational charitable trusts. Despite the fact that the provision of state education was not universal even by the end of the nineteenth century, in 1880 one influential writer suggested that education 'no longer afford[s] a sphere for the operation of [charitable] endowments... [instead] the main office of [charitable] endowments is to afford a field for experiments in benevolence'. ${ }^{167}$ An example of the increasing number of 'experimental' educational charities can be seen in one of the later judicial uses of the public benefit requirement; there, Chitty $\mathbf{J}$ justified upholding a society for the suppression of cruelty to animals on the basis that it

\footnotetext{
162 Ridge, 'Religious Charitable Status', 1076.

${ }^{163}$ Grieves v Case (1792) 4 Bro C C 67; AG v Fowler (1808) 15 Ves Jr 85; Cocks v Manners (1871) LR 12 Eq 574; Yeap Cheah Neo (1874-75) LR 6 PC 381; Re Vaughan (1886) 33 Ch D 187; Re White [1893] 2 Ch 41.

${ }^{164}$ Michael Blakeney, 'Sequestered Piety and Charity - A Comparative Analysis' Journal of Legal History (1981) 207, 213.

165 Cornish et al, Oxford History, Volume XIII, 517.

${ }^{166}$ Education Act 1870 (33 \& 34 Vict., c.75); Rhodes, 'Pluralist Establishment', 874.

${ }^{167}$ Kenny, Charitable or other Public Uses, 24-25.
} 
supported 'the advancement of morals and education among men'. ${ }^{168}$ This is a much broader educational purpose than common educational charities for schools, and was possibly encouraged by the increasing number of such non-standard charitable bequests in light of state education provision. Furthermore, debates about educational change were often intertwined with debates about religious pluralism, meaning that experimental educational trusts often had an added element of controversy or novelty which demanded new substantive reasoning. ${ }^{169}$

Hackney has argued that until the 1930s it was only 'largely' through charities that poor children could receive any advanced education, thus cocooning educational charities from the effects of social change. ${ }^{170}$ However, it is respectfully submitted that even if this is true, we still see a wide variety of purported charitable gifts to educational purposes in the nineteenth century, for example, to museums, academic societies and essay competitions. ${ }^{171}$ These experiments in benevolence tested the boundaries of, and justifications for, charitable validity in these new contexts. The preamble to the 1601 Act did refer to certain charitable purposes, but these were very traditional: 'Schooles of Learninge, Free Schooles and Schollers in Universities'. Thus, as philanthropic gifts were increasingly made for other institutions or types of education, the preamble alone could not provide authority for the charitable status of such gifts. The public benefit requirement would have been a sensible supplement to justify distinguishing cases.

In essence, the influence of the changes in education was negative - there was a decreasing need for one very common charitable purpose. This, combined with a broadening approach to religious matters, created the opportunity for wider individual charitable purposes to be raised in the latter half of the nineteenth century. Decisions on these wider purposes would have needed some sort of justifiable test and the public benefit requirement would have been a sensible response to that need.

\section{Taxation}

In 1799 the Duties upon Income Act was passed as a way of raising funds for the Napoleonic wars. ${ }^{172}$ Section 5 provided an exception for any 'corporation, fraternity or society of persons

\footnotetext{
${ }^{168}$ Re Foveaux [1895] 2 Ch 501, 507.

${ }^{169}$ Cornish et al, Oxford History, Volume XIII, 518.

${ }^{170}$ Jeffrey Hackney, 'The Politics of the Chancery', 34 Current Legal Problems (1981) 113, 119-121.

${ }^{171}$ For these and more cases see: Tyssen, Charitable Bequests, 167-174.

17239 Geo. III, c.13; Fiona Martin, 'The History of the Taxation of Charities: How the Common Law Development of a Legal Definition of 'Charity' Has Effected the Taxation of Charities' in John Tiley (ed.), Studies in the History of Tax Law (Volume 4), Oxford, 2010, 297, 309.
} 
established for charitable purposes only'. ${ }^{173}$ This war-time tax was suspended in 1816, but was reintroduced permanently on substantially similar terms in $1842 .{ }^{174}$ Sections 88 and 105 of the 1842 Act retained the same exception for charitable purposes as the 1799 Act. This was a valuable exception - by the end of the nineteenth century, nearly three million pounds was being granted in tax relief to charities. ${ }^{175}$

As the Bill of Rights 1689 made clear, ${ }^{176}$ taxes could only be levied by parliamentary consent. Tax was therefore entirely a creature of statute, to be interpreted by the judiciary. A strict and literal approach was taken to the interpretation of taxation statutes so as not to favour the Revenue, though exemptions were interpreted liberally to favour the party who purportedly owed the taxation. ${ }^{177}$ Despite this, by 1871 case law had 'yet to make any significant impact' on taxation practice - largely because it was not until 1874 that the courts could review tax tribunal decisions. ${ }^{178}$ Thus, despite an unsuccessful request in 1863 that Parliament should resolve the matter, the definition of 'charitable purposes' for taxation issues was still not settled. ${ }^{179}$

It was the attempt by Gladstone's government to encourage a stricter interpretation of 'charitable purposes' by the Income Tax Commissioners that gave rise to the first cases on the matter. ${ }^{180}$ The first case was the 1888 Scottish decision of Baird's Trustees, which held that 'charitable' required some element of relief for the poor or deprived. ${ }^{181}$ This decision was overturned only three years later in the seminal Pemsel decision. ${ }^{182}$ There, the Income Tax Commissioners had revoked a previously granted exemption to a trust which supported missionary establishments of the Protestant Episcopal church in heathen nations. The trustees successfully appealed against this decision to the House of Lords, where Lord Macnaghten, giving the leading judgment, ${ }^{183}$ famously defined 'charitable purposes'. He held that the definition of 'charitable purposes' under the Act followed the general, technical legal

\footnotetext{
${ }^{173}$ Compare ss 87-88.

${ }^{174}$ Martin, 'History of Taxation', 309.

175 Martin Daunton, Trusting Leviathan: The Politics of Taxation in Britain, 1799-1914, Cambridge, $2007,214$.

1761 Will. \& Mar. II, c.2.

${ }^{177}$ Chantal Stebbings, The Victorian Taxpayer and the Law, Cambridge, 2009, 31-32, 114; for example, Stockton and Darlington Railway v Barrett (1844) $11 \mathrm{Cl} \&$ Fin 590.

178 Chantal Stebbings, 'A Local Tax Rebellion: Popular Perceptions of Income Tax Law in the Nineteenth Century', 22 Journal of Legal History (2001) 45, 50; Statute Law Review Act 1874 (37 \& 38 Vict., c.16) ss 8-9.

${ }^{179}$ Michael Gousmett, The Charitable Purposes Exception to Income Tax, unpublished PhD thesis, $2009,406$. Available at: < ir.canterbury.ac.nz/bitstream/10092/3448/2/thesis_fulltext.pdf > accessed 15 August 2016.

${ }^{180}$ Martin, 'History of Taxation', 310.

${ }^{181}$ Baird's Trustees v Lord Advocate (1888) 15 Sess Cas (4th Series) 688.

182 Special Commissioners for Income Taxation v Pemsel [1891] AC 531.

${ }^{183}$ Lords Watson and Morris agreed: ibid, 563 and 592.
} 
definition, deriving from the preamble of the Statute of Charitable Uses 1601. In doing so, as quoted above, Lord Macnaghten gave his fourfold classification of 'charity', the fourth head covering 'trusts for other purposes beneficial to the community' ${ }^{184}$ Consideration of public benefit was thus central to the definition of 'charitable purpose' under the Income Tax Acts.

It was thus the introduction of new permanent methods of taxation, with an exception for 'charitable purposes', which gave rise to possibly the most famous standalone charitable validity decision. By 1891 we had seen several explicit references to a public benefit requirement, and the social and legal changes of the nineteenth century had largely taken place, so the timing of Pemsel meant it was likely that the presence of public benefit would feature in its seminal definition of charity.

\section{The formalisation of the doctrine of precedent}

There is evidence from the seventeenth century that reports of the Court of Chancery focussed more on prior similar actions than judicial comments, ${ }^{185}$ arguably because the court was concerned more with the merits of individual cases than applying legal rules. ${ }^{186}$ Furthermore, Winders' thorough survey of the history of precedent in the Court of Chancery shows that judges from the seventeenth century often 'consciously and deliberately relied on previous decisions' ${ }^{187}$ However, at this stage the courts seem to focus on the principles underlying a line of previous decisions, and not on particular decisions themselves. ${ }^{188}$

Yet, as has been traced in detail elsewhere, from the beginning of the nineteenth century a more formalised doctrine of precedent starts to emerge. ${ }^{189}$ Hence, in 1834, James Ram's extensive survey of early nineteenth century cases led him to suggest that even a single decision 'may become so fast settled, that the Courts of Westminster Hall may not be able to overturn, or even to shake it, and on the contrary may be bound to follow and establish it' ${ }^{190}$ Not long

\footnotetext{
184 Ibid, 583.

${ }^{185}$ Mike Macnair, 'The Nature and Function of the Early Chancery Reports' in Chantal Stebbings, ed., Law Reporting in Britain (1995) 123, 121.

${ }^{186}$ Neil Duxbury, The Nature and Authority of Precedent, Cambridge, 2008, 53, n 96; Earl of Oxford's Case (1615) 1 Rep Ch 1, 6-7 (Lord Ellesmere LC).

187 W. H. D. Winder, 'Precedent in Equity' (1941) 57 Law Quarterly Review 245, 246.

${ }^{188}$ Jim Evans, 'Changes in the Doctrine of Precedent in the Nineteenth Century' in L Goldstein ed., Precedent in Law, Oxford, 1987, 45; Winder, ibid, 251. Well-known judicial statements of this include: Omichund v Barker (1748), 2 Eq Cases Ab 401, 403 (Parker CB); Jones v Randall (1774) 1 Cowp 37, 39 (Lord Mansfield); and Strother v Barr (1828) 5 Bing 137, 153 (Best CJ).

${ }^{189}$ Evans, 'Precedent in the Nineteenth Century'; Carlton Kemp Allen, Law in the Making, Oxford, 1st ed., 1927, chs 3-4.

${ }^{190}$ James Ram, The Science of Legal Argument, London, 1834, 3.
} 
after, in 1861, the House of Lords confirmed that it was bound by its own decisions, ${ }^{191}$ and from 1895 the Court of Appeal took a strict approach to the binding status of its own decisions. ${ }^{192}$ It was thus in the second half of the nineteenth century that 'the concept of rules of precedent becomes firmly established', although 'many details and refinements of the new systems remained to be worked out in the twentieth century'. ${ }^{193}$

Evans has argued that this development had two main causes: the emergence of the modern structure of the courts, with a clearer hierarchy, and the influence of Benthamite reforms to the legal system generally. ${ }^{194}$ It has also been suggested that Benthamite legal positivism, based on the premise that law is man-made not eternal or discoverable, ${ }^{195}$ influenced judicial thinking. ${ }^{196}$ However, although there is some evidence of Bentham's influence on the thinking of Sir Samuel Romilly ${ }^{197}$ and Sir John Romilly MR, ${ }^{198}$ there is no discernible link between these facts and the development of the public benefit requirement. Therefore, at least in this specific context, only Evans' first two reasons are reliable explanations for the development of precedent in our particular context.

The general development of the doctrine of precedent is reflected in cases concerning charitable trusts. For example, in the early nineteenth century we start to see references to 'the established doctrine of the court' and the 'settled rules of construction' as justifications for deciding charitable validity cases a particular way. ${ }^{199}$ By the end of the century there is at least one explicit statement of the importance of first instance judges adhering to 'a series of decisions' in charitable validity cases. ${ }^{200}$ Furthermore, in eight of the twelve cases cited above in which public benefit was decisive of charitable validity, the court referred to 'the authorities' or something similar in reaching its conclusion. ${ }^{201}$ Three of those cases are explicitly followed

${ }^{191}$ Beamish v Beamish (1861) 9 HL Cas 273; confirmed in London Tramways Co v London County Council [1898] AC 375.

192 Pledge v Carr [1895] 1 Ch 51; Lavy v London County Council [1895] 2 QBD 577.

${ }^{193}$ Evans, 'Precedent in the Nineteenth Century', 57, 64.

${ }^{194}$ Evans, 'Precedent in the Nineteenth Century', 64-72.

195 Jeremy Bentham, Of Laws in General, H. L. A. Hart ed., London, 1970, 1.

196 Evans, 'Precedent in the Nineteenth Century', 70-71; Duxbury, Precedent, 37-48.

${ }^{197}$ They were lifelong close friends and influenced each other's thinking: Peter Medd, Romilly: a life of Sir Samuel Romilly, lawyer and reformer, London, 1968, 70.

${ }^{198}$ Romilly MR was part of the Benthamite Radicals group; something which arguably influenced his attitude towards codification of the law: Ridge, 'Legal Neutrality', 195; and Michael Lobban, 'Preparing for Fusion: Reforming the Nineteenth-Century Court of Chancery, Part II', 22 Legal History Review (2004) 565, 595.

${ }^{199}$ Moggridge v Thackwell (1803) 7 Ves 36, 68 (Lord Eldon LC) and AG v Mayor of Bristol (1820) 2 J \& W 294, 318 (Lord Eldon LC), respectively. Lord Eldon later said that Moggridge was decided 'much against my inclination': Mills v Farmer (1815) 1 Mer 55, 99.

${ }^{200}$ Re Birkett's Trusts (1878) 9 Ch D 576, 580 (Jessel MR).

${ }^{201}$ Rickard v Robson (1862) 31 Beav 244, 246 (Romilly MR); Beaumont v Olveira (1868) LR 6 Eq 534, 318 (Selwyn LJ); Cocks v Manners (1871) LR 12 Eq 574, 585 (Wickens VC); Hall v Derby Urban Sanitary Authority (1885) 16 QBD 163, 171 (Manisty J); Re Vaughan (1886) 33 Ch D 187, 193 and 194 (North J); Re 
in later nineteenth-century cases. ${ }^{202}$ Similarly, we see later cases citing key passages from three of the five cases cited above in which the public benefit requirement was suggested or obiter. ${ }^{203}$ Although these are not necessarily explicit appeals to a formal doctrine of precedent, the charitable trust cases display an increasing tendency on the part of judges to habitually reference and rely on previous cases when reaching decisions. With such a precedent-based attitude to previous decisions developing, it seems a natural consequence that the public benefit requirement could become formally entrenched in charity law as each judicial usage of it increased its status as a binding requirement.

\section{HOW CHANGE WAS MADE: BORROWING FROM THE LAW OF MORTMAIN}

Section $\mathrm{V}$ has shown how four coalescing changes in nineteenth century law and society brought about a need for a change in charity law. Generally, charity law needed to be broadened to cope with the wider range of attempted charitable dispositions being made. However, there needed to be some judicial principle to regulate and consistently justify permissible charitable dispositions, otherwise standard rules of taxation, for example, could be too easily avoided or too harshly applied. When faced with these pressures, judges did not really develop new law, but instead reached for something familiar in a closely related context. The concept which nineteenth century judges used was the public benefit requirement in both its senses - that a disposition had to benefit a section of the public both conceptually and in reality in order to be legally charitable. This was not a totally new concept - mortmain law cases since the turn of the nineteenth century had been discussing the relevance and impact of the presence of public benefit. It is argued here that in the latter nineteenth century, judges borrowed this analysis of public benefit from the mortmain cases, a very different context, to help develop the law of charity generally, thus giving rise to the public benefit requirement.

\section{Mortmain law}

White [1893] 2 Ch 41, 52 (Lindley LJ); Re Foveaux [1895] 2 Ch 501, 505, (Chitty J); Re Nottage (No 1) [1895] 2 Ch 649, 655 (Lindley LJ) and 656 (Lopes LJ).

${ }^{202}$ Rickard v Robson followed in Re Tyler [1891] 3 Ch 252, 244 (Stirling J). Cocks v Manners followed in Re Joy (1888) 60 LT 175, 180 (Chitty J). Goodman v Saltash Corporation applied in: Re Christchurch Inclosure (1888) 88 Ch D 520, 532 (Lindley LJ); Re St Stephen (1888) 39 Ch D 492, 500-501 (Kay J); Re Norwich Town Close Estate Charity (1889) LR 40 Ch D 298, 307 (Cotton LJ); Re White [1893] 2 Ch 41, 52 (Lindley LJ). ${ }^{203} A G v$ Pearce (1740) 2 Atk 87; Jones v Williams (1767) Amb 651; and AG v Heelis (1824) 2 Sim \& St 67. 
Mortmain was the alienation of any lands or tenements to a perpetual legal person, such as a corporation or a charitable trust. The law of mortmain can be traced back to the statute de Viris Religiosis in $1279,{ }^{204}$ and originally focussed on preventing dispositions by will of land to corporations. Accordingly, over time those who wanted to endow the church had to find an alternative method: would-be donors turned to the charitable trust. ${ }^{205}$ In response, the Mortmain and Charitable Uses Act 1736 invalidated any dispositions of land by will to charitable trusts and those made inter vivos within the year preceding the donor's death. ${ }^{206}$ Although originally concerned with preventing the avoidance of feudal incidents, the aim of the law of mortmain after the 1736 Act was to stop potentially perpetual charitable trusts acquiring title to all land in the country, thereby locking it up forever, and, more specifically, to quash the fear that clerics would 'terrorise [the dying] into making death-bed devises ad pias causas to the ruin of their heirs' ${ }^{207}$ This was part of the law's longstanding concern ${ }^{208}$ to limit perpetual devises generally through, for example, the rule(s) against trust perpetuities ${ }^{209}$ and unbarrable entails.

The mortmain statute of 1736 , 'the language of which is certainly very general', ${ }^{210} \mathrm{did}$ not define 'charitable' and it was for the courts to determine its remit. Importantly, in mortmain cases (that is, cases concerning attempted dispositions of land by will to charitable trusts) courts decreed charitable status where they wanted to invalidate the disposition - if the disposition was not charitable, it did not come within the 1736 Act and was a valid gift of land. This means a finding of charitable status was often detrimental to the donee in mortmain, despite usually being a benefit in non-mortmain cases. ${ }^{211}$ The courts were therefore using charitable status in two very different ways in these two kinds of cases.

The courts took a very expansive approach to the $1736 \mathrm{Act}^{212}$ as it was 'a remedial Act, and therefore... to be construed liberally and beneficially, so as to suppress the mischief and advance the remedy'. ${ }^{213}$ This approach was supported by the Act's preamble which stated that gifts of land to charities were 'prejudicial to and against the common Utility'. Although not the only possible means of doing so, a finding of charitable status, followed by invalidation under

\footnotetext{
2047 Edw. I, c.2.

${ }^{205}$ Chantal Stebbings, 'Charity Land: A Mortmain Confusion' 12 Journal of Legal History (2001) 7, 7-10.

2069 Geo. II, c.36.

207 Jones, History, 107; 'to religious charitable causes'.

${ }^{208}$ Arguably stretching back to the Statute of Quia Emptores 1290 (18 Edw. I, c.1).

${ }^{209}$ The first explicit judicial reliance on the public benefit requirement also involved concerns about perpetuities; Rickard v Robson (1862) 31 Beav 244.

${ }^{210}$ Young v Grove (1847) 4 CB 668, 675 (Wilde CJ).

${ }^{211}$ Gardner, Law of Trusts, 100-103.

${ }^{212}$ Kenny, Charitable or other Public Uses, 69-75.

213 Jeffries v Alexander (1860) 8 HL Cas 594, 628 (Byles J). Also: Adlington v Gann (1740) Barn Ch 130, 134 (Lord Hardwicke LC) and $A G$ v Meyrick (1750) 2 Ves Sen 44, 47 (Sir John Strange MR).
} 
the Mortmain Act, was believed to be the best way of protecting next-of-kin from deathbed dispositions. ${ }^{214}$

This expansive approach to the legal meaning of charity prompted increasing numbers of gifts of land to nonstandard purposes to try to avoid the effect of mortmain. ${ }^{215}$ The courts' purposive approach to the legislation in turn led to an increasingly broad interpretation of what counts as charitable in mortmain cases. For example, Lord Camden's broad 'definition' of charity, a gift to a general public use, which was probably the widest approach to charity seen in judicial language by the end of the eighteenth century, was given to enable the voiding of a gift to build and maintain water conduits and reservoirs in Chepstow. ${ }^{216}$ Similarly, in a mortmain dispute concerning a charity to establish a school for local needy children and the testators' descendants, Lord Loughborough stated that 'as far as [the purpose] tends to establish a charity for general purposes, it is void, by the statute of Mortmain'.217

Within a decade, Lord Eldon held that a devise to set up a botanical garden was charitable merely 'upon the expression of the testator, that he trusted it would be a public benefit'. ${ }^{218}$ Usually courts were very wary of following the words of testators, ${ }^{219}$ but here it was done to be able to declare the disposition void under the Mortmain Act. This is a good example of an unusual purpose being held to be charitable under the Mortmain Act.

Shortly after, in the British Museum case of 1826 (concerning another nonstandard purpose - a gift to the British Museum), the word 'charity' under the Act was 'virtually equated' with 'public'.220 There Leach VC stated that 'every gift for a public purpose, whether local or general, is within the [1736 Act], although not a charitable use within the common and narrow sense of those words'. ${ }^{221}$ This very broad attitude to charitable status prompted one commentator to state that 'there is no reported case of a devise [of land] being saved from the Mortmain Act... by a finding that the particular public object was not charitable'. ${ }^{222}$

\footnotetext{
214 Jones, History, 132.

215 As well as gifts to honorary or secret trusts: Chantal Stebbings, 'Roman Catholics, Honorary Trusts and the Statute of Mortmain' 18 Journal of Legal History (1997), 1.

216 Jones $v$ Williams (1767) Amb 651, 652.

${ }^{217}$ Blandford v Fackerell (1792) Bro C C 394, 397.

218 Townley $v$ Bedwell (1801) 6 Ves Jr 194, 198.

${ }^{219}$ E.g. Morice v Bishop of Burham (1805) 10 Ves Jr 522.

${ }^{220}$ Jonathan Garton, Graham Moffat, Gerry Bean, Rebecca Probert, Moffat's Trusts Law: Text and Materials, 6th ed., Cambridge, 2015, 892.

${ }^{221}$ Trustees of the British Museum v White (1826) 2 Sim \& St 594, 596. Also: Blandford v Fackerell (1793) 4 Bro C C 394, 397 (Lord Loughborough); Mellick $v$ The President and Guardians of the Aslyum (1821) Jac 180, 184 (Sir Thomas Plumer MR); Ingleby v Dobson (1828) 4 Russ 342, 344 (Sir John Leach MR); Walker v Richardson (1837) 2 M \& W 882, 892 (Parke B); Thomson v Shakespeare (1860) 1 De G, F \& J 399, 409 (Knight-Bruce LJ).

${ }^{222}$ Jones, History, 128. Jones states that the British Museum decision is 'unsupportable' at 129.
} 
It is true that the courts essentially answered the same legal question in mortmain and non-mortmain charitable trusts cases - whether the purported charitable purpose was valid. However, the above examples show that the courts approached that question in mortmain cases with an inherent bias towards validating the charitable purpose in order to hold the disposition of land void - unlike in non-mortmain cases, where the starting point was that the supporters of a novel charitable purpose had to justify it being upheld. This is because the underlying policy question in the two situations was very different: is this disposition likely to lock up land perpetually contrary to legislation (mortmain), or is this purpose legally worthy of the legal, financial and social benefits of charitable status in perpetuity (non-mortmain). The former question favours finding charitable status to invalidate a disposition; the latter question favours withholding charitable status to maintain taxation revenues and protect resources from perpetual alienation. It is thus submitted that the court's approach in mortmain cases is so different to the court's approach in non-mortmain cases that the two situations should be seen as separate streams of precedent.

This broad and purposive approach to charitable status under the Mortmain Act came to an end in 1891, when Parliament enacted the Mortmain and Charitable Uses Act 1891. ${ }^{223}$ Section 5 allowed express dispositions of land in mortmain, but required the land to be sold within one year of the testator's death. Parliament was taken to have legislated 'all the protection necessary against the acquisition of land by charities', 224 and the bold cases decided under the 1736 Act should no longer have been relevant to non-mortmain charitable validity cases not subject to a purposively-interpreted statute.

\section{Mortmain law: the relevance}

Interestingly, these mortmain cases were decided between 1736 and 1891. This almost exactly maps the period of development of the public benefit requirement for charitable trust validity. The coincidence in time periods perhaps explains the tendency for mortmain cases to creep into non-mortmain charitable trust cases. This is further supported by the fact that, at least in the nineteenth century, the courts would use the Statute of Charitable Uses 1601 as their starting point for determining charitable validity in mortmain cases as they would in non-mortmain cases - although the courts in mortmain cases stretched the analogy process further than in

\footnotetext{
$22354 \& 55$ Vict., c.73.

${ }^{224}$ Re Hume [1895] 1 Ch 422, 436 (Lindley LJ).
} 
non-mortmain cases. ${ }^{225}$ Thus we see judges referencing mortmain cases to support their arguments in seven of the twelve different explicit judicial uses of the public benefit requirement in the context of charitable validity (Rickard v Robson, ${ }^{226}$ Beaumont v Oliveira, ${ }^{227}$ Re Vaughan, ${ }^{228}$ Re Joy, ${ }^{229}$ Pemsel, ${ }^{230}$ Re White, ${ }^{231}$ and Re Foveaux ${ }^{232}$ ), and in four of the five implicit reference cases ( $A G v$ Whorwood, ${ }^{233}$ Jones $v$ Williams, ${ }^{234}$ Grieves $v$ Case, ${ }^{235}$ and $A G v$ Heeli $\left.^{236}\right)$. Further, counsel's argument in Thompson $v$ Pitcher $^{237}$ was in the context of a mortmain case, and in Morice counsel at first instance, ${ }^{238}$ and on appeal, ${ }^{239}$ supported their arguments based on public benefit by citing mortmain cases. Indeed, judges continued to conflate mortmain charitable validity cases and other charitable validity cases even after the 1891 Act was passed. ${ }^{240}$

It is unclear whether this doctrinal borrowing from mortmain case law was unintentional or tactical. On the one hand, the continuing use of mortmain cases in nonmortmain cases may simply have resulted from unintentional conflation of principles which were commonly relevant to previous cases. Half of our key judicial usages of the public benefit requirement involve high value dispositions of personalty; one quarter concerning stocks, ${ }^{241}$ the other quarter cash sums. ${ }^{242}$ Charitable gifts of high-value personalty was a relatively new

${ }^{225}$ Thornton v Howe (1862) 31 Beav 14, 19 (Romilly MR); Burnaby v Barsby (1859) 4 H \& N 690, 695 (Watson B); and Shelford, The Law of Mortmain, 58. This is arguably implicit in Lord Camden's 'definition' of charity in Jones $v$ Williams (1767) Amb 651, which finishes 'many instances in the statute 43 Eliz. carrying this idea'.

226 (1862) 31 Beav 244; citing Thornton v Howe (1862) 31 Beav 14, decided just two weeks earlier by the same judge, Sir John Romilly MR.

227 (1868) LR 6 Eq 534; citing Robinson v Geldard (1852) 3 M \& G 735.

228 (1886) 33 Ch D 187; citing Champney v Davy (1879) LR 11 Ch D 949.

229 (1888) 60 LT 175; citing The University of London v Yarrow (1857) 1 De G \& J 72.

230 Special Commissioners for Income Taxation v Pemsel [1891] AC 531; citing The University of London $v$ Yarrow (ibid).

231 [1893] 2 Ch 41; citing Baker v Sutton (1836) 1 Keen 224.

232 [1895] 2 Ch 501; citing Thornton v Howe (1862) 31 Beav 14 and The University of London v Yarrow (1857) 1 De G \& J 72.

233 (1750) 1 Ves Sen 534; discussing the college's own mortmain rules.

234 (1767) Amb 651; a mortmain case. The reporter references Lord Camden's 'definition' of charity as the much later case of Trustees of the British Museum v White (1826) 2 Sim \& St 594, a mortmain case which did not itself mention Jones.

235 (1792) 4 Bro C C 67; a mortmain case.

236 (1824) 2 Sim \& St 67; citing AG v Brown (1822) 6 Madd 304 (decided by the same judge, Leach VC).

237 (1815) 6 Taunt 359.

${ }^{238}$ Morice v Bishop of Durham (1804) 9 Ves Jr 399, 400; three of their four cases were mortmain cases: $A G v$ Whorwood (1750) 1 Ves Sen 534 Townley v Bedwell (1801) 6 Ves Jr 194; Corbyn v French (1799) 4 Ves Jr 418.

${ }^{239}$ Morice v Bishop of Durham (1805) 10 Ves Jr 522, 523; citing: AG v Lady Downing (1767) Wilm 1; AGv Bowyer (1798) 3 Ves Jr 714.

${ }^{240}$ E.g. Special Commissioners for Income Taxation v Pemsel [1891] AC 531, 582 (Lord Macnaghten).

${ }^{241}$ Rickard v Robson (1862) 31 Beav 244; Re Vaughan 1886) 33 Ch D 187; Re Foveaux [1895] 2 Ch 501; and Re Nottage (No 1) [1895] 2 Ch 649.

${ }^{242}$ Jones $v$ Williams (1767) Amb 651, AG v Pearce (1740) 2 Atk 87, Beaumont v Oliveira (1868) LR 6 Eq 534 and Re Joy (1888) 60 LT 175. 
type of legal giving as it was only from the nineteenth century that assets of considerable value other than land increased substantially. ${ }^{243}$ It is thus possible that judges and lawyers unintentionally introduced the importance of public benefit, traditionally only relevant to charitable gifts of land, into new discussions concerning charitable gifts of personalty.

Conversely, this doctrinal borrowing may have been a tactical choice by judges who wished to use the broad mortmain approach to defining charity to facilitate generosity towards novel (now socially favoured) charities. It is submitted that given the frequency of this intermingling of mortmain cases and non-mortmain cases, it is unlikely that this borrowing of the language of public benefit was wholly accidental. Furthermore, as has been shown in section $\mathrm{V}$, during the nineteenth century society began to accept a much broader range of purposes as charitable. If generally adopted, the wide conception of public benefit developed in the (specific) statutory mortmain context to counter perpetuities would have allowed many of these new socially-acceptable charitable purposes to be granted legal validity in nonmortmain cases without the creation of new, untested legal ideas. In short, it would have been a sensible and easy step for nineteenth century judges to formalise a public benefit requirement by borrowing from mortmain cases in order to meet the pressures, caused by the first three factors outlined above, for a wider legal definition of charity generally. Once this was attempted a few times, as the cases in section IV evidence, the public benefit requirement could quickly become binding under the developing doctrine of precedent.

In summary, nineteenth century judges and counsel often drew no clear distinction between cases where a finding of charitable status was a benefit to the charitable purpose (where the charitable gift of personalty is valid) or a disadvantage (where mortmain invalidated a gift of land). When such a distinction is obscured the development of the rules of charitable validity seems haphazard at best. However, although it is unclear whether the continued use of the language of public benefit after the abolition of mortmain was always intentional, given the frequency of mortmain cross-referencing it seems plausible to suggest that judicial borrowing from mortmain cases was the source of the development of the public benefit requirement.

\section{CONCLUSION}

\footnotetext{
${ }^{243}$ Martin Daunton, 'Society and Economic Life' in Colin Matthew ed., The Nineteenth Century: The British Isles 1814-1901, Oxford, 2000, 43-55; Tom Nicholas, 'Businessmen and Land Purchase in the Late Century' 52 Economic History Review (1999), 27; Anne Lawrence, Josephine Maltby and Janette Rutterford, Women and Their Money 1750-1900, London, 2009, 86-88.
} 
Today, to be valid a charitable trust must be for the public benefit. However, just over 150 years ago, judges did not use the public benefit requirement to determine charitable validity. This article has tracked the express and implied references to the public benefit requirement to describe its trajectory from a rhetorical device to a legal requirement. More importantly, this article has demonstrated that four legal and social factors coalesced in the nineteenth century to form the catalyst and need for the adoption of the public benefit requirement. The educational, religious and taxation changes of the nineteenth century provided the perfect opportunity for new charitable purposes to be tested and the criteria for charitable validity to be revised. In addition to historic references, the law of mortmain provided a transferrable conception of the public benefit requirement which could be adopted to regulate the changing law of charity under a developing doctrine of precedent.

\section{Acknowledgments}

This article is based on a dissertation submitted in 2014 as part of an LLM at University College London. I would like to thank Dr Ian Williams for his very generous guidance and support both as a supervisor and tutor during the course and afterwards. I would also like to thank Professor Charles Mitchell, Mr Jeffrey Hackney and the anonymous reviewers for their helpful ideas and comments. All opinions and errors remain mine alone.

\section{Notes on contributor}

Matthew Mills is a non-stipendiary lecturer in Land Law at Oriel College, Oxford University. He has also been a teaching fellow in Trusts at University College London. He was called to the Bar by Lincoln's Inn 